\title{
THEN THE WEST IS FAR AWAY: ROMANIAN ATTEMPTS TO WITHDRAW FROM WORLD WAR II (1943-1944), FINNISH VIEWS
}

\section{Silviu Miloiu}

Valahia University of Targoviste, E-Mail: silviu.miloiu@valahia.ro

\section{Acknowledgments}

This paper is based on the presentation made at the Fifth international conference on Baltic and Nordic Studies in Romania A piece of culture, a culture of peace, re-imaging European communities in the North Sea, Baltic Sea and Black Sea regions, hosted by Valahia University of Târgovişte and the Romanian Association for Baltic and Nordic Studies, August 17-19, 2014. Supported by EEA Grants, contract no 4/22.07.2014.

\begin{abstract}
:
This article approaches the Romanian foreign policy stakes in the aftermath of the Stalingrad Battle as seen from the perspective of a comrade-in-arms country, Finland, which shared with Romania many of the assumptions, fears and anxieties with regard to the outcome of the war. The article is shaped in Stephen M. Walt's understanding of balancing and bandwagoning, Romania and Finland choosing Germany over the Soviet Union mainly for the reason that the latter was perceived as the biggest security threat and the former as the only possible deterrent and support. The material focuses on the analysis of Eduard Hjalmar Palin's diplomatic dispatches from Bucharest. On one hand, they were the main source of information for the Finnish decision-makers with regard to the Romanian international situation and its foreign and domestic policies. On other hand, Palin was an experienced diplomat, with excellent connections in the Romanian society and enjoyed access to confidential information in the governmental circles due to a Romanian-Finnish agreement of summer of 1941. We can see, for instances, cases when Ion and Mihai Antonescu confided to the Finnish envoy Führer Adolf Hitler's statements which could affect the situation in Finland or help its leaders to take decisions. The article shows how divided Romanian governmental and opposition circles were, not only between but also among themselves. By reading these diplomatic reports, we could also acknowledge the widening split between the views of the two most prominent Romanian governmental leaders, Ion and Mihai Antonescu, thus complementing other sources of information already published. We can also learn about some peace plans of Romanian opposition groups, some of whom are little known from other documentary sources.
\end{abstract}

\section{Rezumat:}

Acest articol abordează problemele și dificultățile ce stăteau în fața politicii externe românești ca urmare a rezultatului Bătăliei de la Stalingrad, privite din perspectiva unei 
țări, Finlanda, care era camarad de arme și care împărțea cu România multe dintre asumpțiile, temerile și îngrijorările cu privire la rezultatul războiului. Articolul este elaborat în sensul înțelegerii pe care o dă Stephen M. Walt conceptelor de balanță de putere şi bandwagoning (aliniere), România și Finlanda alegând Germania în dauna Uniunii Sovietice în principal prin prisma faptului că cea din urmă era privită drept cea mai importantă amenințare de securitate, în vreme ce prima era considerată ca singura forță de descurajare și sprijin posibilă. Materialul se concentrează asupra analizei depeșelor diplomatice trimise din București de către Eduard Hjalmar Palin. Pe de o parte, acestea constituiau principala sursă de informații pentru factorii de decizie finlandezi cu privire la situația internațională a României și la politicile sale externe și interne. Pe de altă parte, Palin era un diplomat experimentat, cu excelent conexiuni în societatea românească, ce se bucura de acces la cele mai confidențiale informații în cercurile guvernamentale, în principal grație înțelegerii româno-finlandeză din vara anului 1941. Putem fi martori, spre exemplu, la situații în care Ion și Mihai Antonescu i-au transmis lui Palin pentru conducerea țării sale confesiuni de-ale lui Adolf Hitler care puteau afecta situația acestei țări sau ajuta la adoptarea unor decizii de către liderii acesteia. Articolul arată cât de divizate erau cercurile guvernamentale și de opoziție din România, nu numai unele față de altele, dar în interiorul lor. Când citim aceste documente diplomatice putem ințelege ruptura tot mai profundă ce se deschidea între cele două cele mai importante figuri guvernamentale românești, Ion și Mihai Antonescu, ceea ce completează alte surse de informații deja publicate. Putem cunoaște, de asemenea, unele planuri de pace ale grupărilor românești de opoziție, unele dintre acestea puțin cunoscute din alte surse documentare.

Keywords: Romanian, Finland, views, perceptions, World War II, bandwagoning, balancing

\section{Introduction}

The Battle of Stalingrad constituted a turning-point in the history of the World War II and was perceived as such both in Bucharest and Helsinki. When viewed against the backdrop of Third Reich's failure to conquer Moscow and thus to end the war in the first year from its outbreak, the German defeat caused at least equal worries and astonishment in the two capitals as the French defeat at the hands of the Wehrmacht in the summer of 1940. The subsequent chain of Soviet victories only added to the Finnish and Romanian leaders' concerns with what the future had in store for their countries. It was not only the change of the strategic initiative on the Eastern Front and elsewhere that worried them. Under the pressure of vicissitudes originating from the new military course on the Eastern Front, opposition groups started to blend in loose peace groupings aimed at convincing the power holders to separate themselves from Berlin and to reach a compromise with the Western Allies. The drama of both authorities and opposition was that the West was far away and had only limited power of influence over developments in their region. Nevertheless, only few of them proved capable of understanding that this situation was going to continue for 
many decisive years in the history of their countries. Some of the gloomier, whether in the government or in opposition, maintained that their countries' only chance may actually be a heroic downfall. Therefore, they tended to support the continuation of the war until the last straw of energy. The more confident considered that the safeguarding of their countries' independence was still possible on the condition that negotiations for an armistice were started with the Western Allies or even with the Soviet Union. The members of the governments in Helsinki and Bucharest, upon whose shoulders the decision rested, were also split. Some argued that, on the condition that they resisted long enough, the redemption was still possible. They tended to advocate for the beginning of a dialogue with the Allies. Only few of them were prepared to start intense negotiations with Stalin. Even the more anti-Communist politicians had understood that their dreams of gaining 'vital space' in the east and of uprooting the Bolshevism from the face of the earth had failed to materialize. This attitude will trigger even bigger criticism against the government originating from those who considered that an energetic pursue of negotiations with the enemy was the only way to protect their nations against an even drearier future.

Due to similarities between the two countries' international situation during these crucial years, this article shall focus on analysing the Finnish perception of developments in Romania. This approach is not an account of the FinnishRomanian relations of these crucial war years. It does not claim that information that the Finnish envoy dispatched to Helsinki was always or entirely accurate, although this was the case most of the time. The goal is to bring a contribution to a better knowledge of the way the situation of Romania was assessed in a country which largely faced the same challenges and was forced to bandwagon Germany in order to oppose to Soviet Union's conquering ambitions. ${ }^{1}$ Since the most persistent and trustful (from the Finnish perspective) source of information about Romania was the Finnish Legation in Bucharest, I chose to focus on the research of reports, telegrams and letters originating from this diplomatic mission under the lead of the experienced diplomat Eduard Hjalmar Palin. Most of the documents researched may be found in folder C 14 in the Finnish Foreign Ministry Archives. The analysis is based on the documents dispatched from Bucharest starting with early spring of 1943 until the Romanian war turnabout of August 1944. A Swedish-Finn with conservative views, Palin understood the apprehensions of the Romanian leaders following the outcome of the Stalingrad Battle. He was able to build a bond of mutual trust with the Romanian dictator, Ion Antonescu, and his deputy, Vice-President of the Council of Ministers and

${ }^{1}$ Further on this, Silviu Miloiu, "From "allies without alliance" to concerted action: Romania and Finland in the aftermath of the Operation Barbarossa (1941)," Revista Română pentru Studii Baltice şi Nordice / The Romanian Journal of Baltic and Nordic Studies 2, Issue 2 (2010): 249-284. 
Foreign Minister Mihai Antonescu. This will help him being always wellinformed of Romanian attitudes and views, which he conveyed to Helsinki.

I have already referred to the concept of bandwagoning. In the context of Romania and Finland's position during the World War II, however, the two counties could not afford to choose between friends and enemies. They closed ranks with Germany in order to balance the Soviet Union, which they perceived as the biggest threat. Their elites, to a large extent, were pro-Western, although at the time of German victories, in 1941-1942, some of their leaders started to entertain hopes that safer border could be gained in the east in the aftermath of the war. Particularly in Romania, Nazi Germany ideology started to be imitated, Jews to be persecuted, "new speech" to be used, although the leaders at the helm of the state were Nationalists Conservative more in tone with the ideology of predecessors of Nazi government of the kind of Franz von Papen or Alfred Hugenberg than with the Hitlerites'. Therefore, we agree with Stephen M. Walt's amendment to the theories of balancing and bandwagoning, which aptly applies also in our case:

Balancing and bandwagoning are usually framed solely in terms of capabilities. Balancing is alignment with the weaker side, bandwagoning with the stronger. This conception should be revised, however, to account for the other factors that statesmen consider when deciding with whom to ally. Although power is an important part of the equation, it is not the only one. It is more accurate to say that states tend to ally with or against the foreign power that poses the greatest threat. ${ }^{2}$

This also explains the nightmares of Romanian and Finnish decision-makers and opposition forces in the context of the German-Soviet war. On one hand, the power they bandwagoned was not only behaving increasingly onerous with its own allies (a behavior which went to the point of occupying Hungary in spring 1944), but was also showing all signs of losing the war. On other hand, the Soviet Union continued to pose the biggest threat to the security of these states, not solely to their external freedom and their territorial integrity (which they saw in terms of interwar national integrity), but also to their domestic freedoms. Its totalitarian regime was even more frightening than the Nazi one, which allowed some space of maneuver, especially in terms of economic freedoms, and was not showing, at least on the short run, a tendency to Nazify these states. Finally, both the elites and opposition groupings in these countries - and we will insist in this article on the case of Romania - could not lose sight of the prospect of a new Nazi-Soviet rapprochement, which could only be accomplished on their expenses.

\section{The time of peace plans}

As Palin noticed in his reports, the Romanian political leadership's need for justifying the foreign policies they had pursued since June 1941 became more apparent after Stalingrad. This was an important vehicle the regime used to claim that it was national interest that was guiding their policies and that their war

2 Stephen M. Walt, "Alliances: balancing and bandwagoning," at http://www.ou.edu/uschina/texts/WaltAlliances.pdf (accessed on 15.11.2014), 112. 
choices were not based on ideology or sympathy for the Germans. By such means, it was assessed by some power groups in Bucharest and Helsinki that a rapprochement with the Great Britain and the United States was possible, not excluding also the possibility of detaching the Western powers from their Soviet ally. The Soviet Union was blamed for forcing these states to abandon their neutrality and take sides with the Germans. For instance, the $25^{\text {th }}$ anniversary of the unification of Bessarabia with Romania, celebrated in Chișinău, occasioned a speech by Marshal Ion Antonescu, where the Leader of the Romanian State (Conducător) detailed the reasons prompting his country to join in the war against Soviet Union and exposed the war aims of his regime. Antonescu concentrated his talk on the Soviet takeover of Bessarabia and Northern Bukovina in June 1940. The speaker also pointed out Soviet Union's imperialistic designs over Romania following the takeover of these territories. In this respect, he recalled the acquisition of the islets at the mouths of the Danube in the autumn of 1940 and the evidence proving the Soviet intent to control the traffic on the Danube and the Black Sea. He interpreted Soviet policy as a proof that Stalin's real scope was the expansion towards the Straits and the Adriatic Sea. Additionally, Antonescu recalled the hardships endured by the Romanian people of Bessarabia and Northern Bukovina under Bolshevik yoke. Consequently, Romania's actual foreign policy design when it adopted the decision of joining forces with Germany in the Barbarossa Operation was not the acquisition of foreign territories. He defined it as essentially a defensive struggle for defending the borders of the country, 'the values of the European civilization' and the Christian faith. The Finnish envoy to Bucharest, Palin, commented this speech as underlining once more the uniformity existing between 'the situation, the objectives and viewpoints of Finland and Romania.' ${ }^{3}$ The problem with Antonescu's argumentation was that it did not provide a proper justification for the presence of Romanian Army on the battlefields in Ukraine and Russia. Additionally, it did not reveal anything about the increased Romanian dependence on Germany and did not present any egress of a situation that started to be potentially threatening to his country. Moreover, his speech is an example of using otherness arguments and redrawing the mental map of Europe. Concepts such as civilisation, Christian belief are employed as ideological weapons against the Soviet Union.

The war weariness and the unlikelihood that the Axis will end in the victorious camp were obvious in the Romanian official or unofficial projects to withdraw from the conflagration. A peace opposition was gradually being formed in Romania. As the Finnish envoy informed his foreign minister, a prominent

3 Palin's report no. 12 of 29.03.1943. Ulkoasiainministeriön arkisto (hereafter, UA), 5, C 14. 
Romanian personality drew up a 'peace offensive project', whose content had been handed to him. Palin sharply criticised the project (envisaging the cooperation of Romania and Finland), which he held utopian, thoughtless and hazardous. Yet, the Finnish Minister considered that the real value of the memorandum rested with the fact that it expressed excellently, in all its ambiguous nature, the viewpoints, aspirations and hopes of a large 'circle' of Romanians. What united these Romanians was their belief that Germany was undoubtedly going to lose the war. A consequence of this perspective could be the ruin of small states fighting on Reich's side in the hands of Bolshevism when Germany would collapse. This approach led many Romanians to believe that no means no matter how fantastic and hazardous ought to be abandoned untried, and no price had to be considered too high in order to protect themselves by throwing in their lot with the Anglo-Saxons. This was considered the only chance to avoid Soviet Union occupation. ${ }^{4}$

It was not only the peace opposition who was concluding that Germany was losing the war and that Romania badly needed to find a way to withdraw from the belligerence in order to avoid a frightening situation. After Stalingrad, Mihai Antonescu, as he confessed to the Finnish envoy, also distrusted the possibility that Germany could win the war. The vice-President of the Council of Ministers did not conceal his worries from the Finnish envoy, a man he trusted. Repeatedly, Mihai Antonescu complained of the German behaviour towards the small states. The Romanian chief of diplomacy stressed that the reason of Romania being at war against Soviet Union was the outcome of the fact that she lacked any other viable option in June 1941. Besides, the Romanian government trusted Germany with the capacity of treating with her small allies and of acting as the new organiser of Europe. The expectation was that the German Europe ought to find room for sovereignty and possibilities of development for the smaller European states. As this was not happening, Mihai Antonescu was disappointed. He revealed to Palin his deep dissatisfaction with Germany's behaviour in this regard and pointed out the German retaliation against any ally who dared to diverge from Germany in defending his country's interests. This led him concluding that Germany was not his country's friend. ${ }^{5}$

Gradually, the Finnish envoy gathered information that Mihai Antonescu was taking steps for accommodating his country to the changing fortunes of war. In doing so, he did not lose sight of the possibility that Hitler and Stalin may sign a new agreement similar to the Ribbentrop-Molotov Pact. Therefore, he acted prudently and was favouring a scheme binding together all Germany's allies. They were to convince the Reich to negotiate without delay peace with the Anglo-

4 Palin's letter no. 427 of 17.06.1943 to Ramsay, UA, 5B Bucharest. Eduard Palin, 1943-1944.

5 Palin's letter no. 431 of 22.06.1943 to Ramsay, UA, 5B Bucharest. Eduard Palin, 1943-1944. 
Saxon Powers and thus save what could still be saved. Even this hypothesis was under careful consideration in order to avoid a situation when Germany and Japan joined hands with Soviet Union on the small states' expense.6 Other dilemmas Mihai Antonescu was facing regarded the role of regional powers surrounding Romania and Finland, and of overseas great powers, in the war developments. In case of Romania, the regional powers potentially having an influential voice in any calculations were Italy and Turkey, whereas in the case of Finland, it was Sweden. The reactions of these countries to a change in foreign policy stance had to be carefully considered before starting any such undertaking. Moreover, the most salient factor in this scheme was the possibility to have Anglo-Saxon troops in the neighbourhood of Romania and Finland before taking any risk. ${ }^{7}$ The Romanian Foreign Minister did not conceal his feelings from the Germans. This became more obvious by early summer of 1943 when he demonstrated his independent conduct by turning down a German request to cancel a meeting he was planning with the Pope. He also supported Queen Mother's visit to Italy in order to use her influence in this country on behalf of her country's interests. ${ }^{8}$

The views of the military was also of interest to the Finnish envoy. He sought a private talk with the defence minister, General Constantin Pantazi. The Romanian cabinet member complained that, in articulating the foreign policy, many factors of crucial importance were unknown to the extent that all the assessments and decisions are uncertain from the bottom. Among these uncertainties, Pantazi quoted the military potential of Britain and the United States, especially after their losses in the Battle for the Atlantic, the effects of the Allied bombing - on German war production facilities and its submarine bases - on the German war potential and, finally, the Soviet war potential. Moving to certitudes, Pantazi deplored the general military environment where Germany was obliged to divide her forces into all directions because of the fears of an Anglo-Saxon landing and the necessity to maintain the eastern front. Pantazi viewed the landing into Fortress Europe with doubtful eyes. The effect of this uncertainty, however, was that Germany and its allies had to take into account any risk regarding the time and place of landing. He tended to consider that the elements of risk and the weak points of Germany's defence were centred on the Mediterranean Sea: the domestic situation in Italy or the prevailing mood of the Greeks and Serbians. As he was rather dismissive of the possibility of the creation of a permanent second front in Europe, Pantazi held as a more dangerous security risk an Anglo-Saxon pressure on Turkey in order to agree to allow the passage of their troops through

\footnotetext{
6 Palin's letter no. 431 of 22.06.1943 to Ramsay, UA, 5B Bucharest. Eduard Palin, 1943-1944.

7 Palin's letter no. 431 of 22.06.1943 to Ramsay, UA, 5B Bucharest. Eduard Palin, 1943-1944.

8 Palin's report no. 23 of 25.06.1943. UA, 5, C 14.
} 
this Euro-Asian nation. This would entail for Romania the possibility that the oil region would become a target of the Allied military aircraft. The Minister of Defence pointed out that the Wehrmacht was guarding the European continent from the Arctic Ocean to the Black Sea. He predicted that an 'oxygenated' Red Army was planning a large scale summer offensive. Yet, he held the opinion that it was a matter of time (one year, he assessed) before the Red Army reached the limits of its military capabilities. ${ }^{9}$

On September 10 $0^{\text {th }}$ Palin reported to Helsinki about an important conversation with Marshal Antonescu and M. Antonescu held at the marshal's private residence at the outskirts of Bucharest. The meeting was occasioned by a secret communication of Ion Antonescu in his capacity of chief of state. Antonescu insisted on the necessity that the communication, a Hitler's declaration confided to him at Hitler's headquarters, was dispatched by courier and be read only by Ryti, Mannerheim and Ramsay. Antonescu insisted that no one, not even Ribbentrop, was present at this meeting. Antonescu committed the indiscretion only because he understood the importance of Hitler's declarations for Finland, and he wanted to offer a new evidence of Romania's willingness to enhance the intimate cooperation between the countries which he deemed essential. The essence of Hitler's statement was that he had nothing against Finland concluding a separate peace. Quite the opposite, he considered such a withdrawal to be in the advantage of Germany because it freed seven German divisions and shortened the eastern front. However, according to Antonescu, Hitler took care to emphasise that, despite this, Finland was in the impossibility to broker peace, as the Americans had asked them to do, by turning directly to Moscow, which was impossible to be accepted in Helsinki. Antonescu was in any case puzzled whether to credit or not Hitler's statement because of the importance of the Finnish front. Palin was also suspicious of Hitler's reason to express that way to Antonescu. ${ }^{10}$ Antonescu also recorded that during the conversations, Hitler mentioned the possibility of a withdrawal from the eastern front, without having been yet taken a decision in this sense. Hitler mentioned that, in case of necessity, the northern front was going to be withdrawn along Lake Peipsi and the Estonian border, expressing regrets that the Soviet defence of the front surrounding Leningrad had been successful. At Antonescu's suggestion that, since retreats of the eastern front towards Romania and Finland were envisaged, a withdrawal of troops from Norway was desirable, der Führer refused to take into consideration such action on the ground that they were necessary for providing access to minerals in Scandinavia. At Antonescu's observation that withdrawal of the eastern front would signal increased isolation of Finland and her leaving to her

9 Palin's report no. 19 of 11.05.1943. UA, 5, C 14.

10 Palin's letter no. 558 of 10.09.1943 to Ramsay, UA, 5B Bucharest. Eduard Palin, 1943-1944. 
fate eventually leading to capitulation, Hitler had refused to go deeper into the subject. However, he made the pledge that a German-Soviet separate peace was out of the question. As Palin noticed, Mihai Antonescu disbelieved this promise as he possessed information according to which such feelers were in fact put by Germany. The two leading Romanian politicians approached also in their conversation with the Finnish envoy the possibility of an Anglo-Saxon landing from Italy in the Balkans and its effects on Romania and the back-on-the-agenda topic of the Romanian-Hungarian relations. ${ }^{11}$

The international developments were attentively monitored by the two governments. For instance, the United Nations' meeting of the foreign ministers hosted by the Soviet Union's capital drew their attention. The reason for such concerns being expressed rested with the anticipation that Stalin, during the meeting, was going to express far-reaching territorial and political requests. Moreover, it was considered likely that they would be accepted by Britain, a country considered willing to award extremely significant concessions to Russia in order to maintain the relationship and to prevent a possible agreement between Germany and Soviet Russia, hoping that sometimes in the future she would be able to free herself from this understanding. In order to get a better picture, Palin approached the issue in his dialogue with the new French envoy to Bucharest, Paul Morand. Morand shared the opinion that the conference would approach Europe's future organisation and Russia's demands for strengthening her security. The French diplomat estimated that the Soviet imperialistic demands threatened the Soviet neighbours, and he considered likely that these designs were closed to what Molotov demanded from Hitler in 1940. The Soviet priorities included Poland, the Balkans and the achievement of Soviet aim of a direct connection to the Mediterranean Sea, Stalin's basic scope. Ranking Soviet priorities, Morand considered that Stalin's expansionist designs in the direction of Finland were of a secondary importance compared to his ambitions in the Balkans. The French envoy also believed that Britain, fearful of a likely SovietNazi agreement, was ready to make concessions within a certain limit that could not be exceeded. Instead, he considered that the United States were going to oppose to extensive concessions to the USSR and to keep up their war aims such as acquiring world dominion, which was opposed by both the USSR and the UK. This led Morand to believe that the meeting was going to end in a failure concealed behind decorative press releases. ${ }^{12}$

Following the conference, Palin approached the Turkish ambassador Suphi Tanrioer whose opinion was that the significance of the Moscow Conference and the USSR's gains during the meeting were vastly exaggerated. According to

11 Palin's letter no. 558 of 10.09.1943 to Ramsay, UA, 5B Bucharest. Eduard Palin, 1943-1944.

12 Palin's report no. 30 of 13.10.1943. UA, 5, C 14. 
Tanrioer's information, the conference had only agreed on short-term policies such as the conduct of war, not on the European post-war organisation, or on the future borders of the Soviet Union, the more so as the attending parties demonstrated in many instances divergent views regarding fundamental issues. Neither Eden nor Hull had any powers to settle Europe's post-war organisation, they were only entitled to clarify Soviet Union's intentions and resources. The Turkish ambassador was therefore considering that Britain was the real winner of the conference. His arguments were also geopolitical, arguing that the very existence of the British Empire called for an intransigent opposition to Soviet expansion, especially in the Balkans. Ideological commandments also requested that. Additionally, Tanrioer shared his information according to which Soviet Union had become exhausted with her agriculture and industry deeply affected by the war whereas the United States and Britain were increasing their strength. In plus, the moral stand of the two powers was greater than that of Soviet Union. Resulting from these estimations, Tanrioer's opinion was that Britain watched that both Romania and Finland maintained their vital forces as independent states, although they might be obliged to give up portions of their national territories to the USSR, in case of Romania what it had lost in 1940. As a proof, Tanrioer recalled the declaration that the four powers adopted during the conference, which he considered encouraging for Romania and Finland. Palin was however more sceptical as he assessed that even if the two western powers had such intentions, the defeat of Germany and the vindictiveness by the end of the conflagration might turn empty these plans of keeping in check Soviet aspirations. Tanrioer also anticipated that while the war drew to an end Turkey might step into the conflict, not in order to support Soviet Union, an inimical power, or to put Germany to the sword, but to prevent the Communisation of the Balkans. ${ }^{13}$

Palin enjoyed access to documents regarding the Romanian negotiations for an armistice to be concluded with its enemies. On January 25th 1944 he reported to Helsinki about a contact established between Romanian envoy to Ankara Alexandru Cretzianu and a British official. The conclusion of the conversation was that the Soviet Union would respect the territory of Romania if a democratic government would be formed in this country prepared to conclude an armistice. However, the British official underlined that the Soviet Union was adamant in claiming Bessarabia and Northern Bukovina because of strategic considerations. The chance that relations between the Soviet Union and its Western allies would break up while the war was still raging was dismissed by the British official. The Romanians were advised to contact directly the Soviets in a neutral capital such

13 Palin's report no. 33 of 7.11.1943. UA, 5, C 14. 
as Stockholm. The possibility of alimentary support for a new Romanian government was also approached. Palin concluded that the British were extending their support to King Mihai and that all other considerations were for the time being subordinated to the military considerations. ${ }^{14}$

In his assessment of March 1st, Palin analysed the implications of Antonescu's visit to Hitler at the end of February 1944. Palin also approached the vice-PM regarding the results of this visit, only to find the latter in a bad mood. According to Mihai Antonescu Hitler did not accept the Romanian request for a withdrawal of its divisions from Crimea before the situation would become so dangerous as to threaten with their total annihilation. If the prospect would grow grimmer, the Germans promised their support for transporting these divisions to Romania. During the visit, Jodl presented the military situation to Antonescu. The officer's conclusion was that Germany was capable of holding the advance of the Soviets on the eastern front where only minor retreats might be ordered, while also disposing of the necessary troops to prevent any Anglo-American landing on the eastern front. Marshal Antonescu was obviously impressed by this presentation which raised his spirits as Mihai Antonescu confessed to Palin. The Germans also convinced the Marshal that Turkey would continue its neutral policy. Regarding Finland, Hitler confided to Antonescu that the Finns would not agree to conclude a separate peace with Soviet Union because of the harsh terms claimed by the latter. On the other hand, Ribbentrop was more vague and pointed out that the Eduskunta was having a pivotal role in this regard, and it was difficult to determine what the latter's attitude would be. Marshal Antonescu however concluded that Hitler's stance toward such possibility had changed since the past fall. In general, the vice-PM was unsatisfied with the results of his visit which he did not attend, the Marshal being accompanied only by General Ilie Şteflea, the chief of the General Staff, and Colonel Radu Davidescu, the chief of Marshal's cabinet. 15

Palin noticed in his account of mid-March 1944 the interest manifested in Romania towards the developments taking place in Finland. This attention was visible in the way the Finnish negotiations of armistice made headlines in Romanian press and even more in daily articles and leading articles approaching the Finnish latest developments. Palin considered that, without exception, journalists understood the difficulties of the situation in Finland. This interest was accompanied by 'a sincere compassion, by understanding, respect for the situation in Finland, regardless of the decisions she might adopt and their consequences'. As far as the Romanian position was concerned, Palin discovered a sharp separation between those who disbelieved that there was any chance to 
avoid Soviet occupation of Romania with all its consequences, and those assuming that continuation of resistance and the winning of additional time represented a means towards a possible escape. Everyone accepted the view that where the ceasefire conditions remain similar to those offered by Soviet Union, Finland and Romania ran into considerable risks. There were similarly divergent views regarding the future of relations between Britain, the United States and the Soviet Union. There were those arguing that the alliance between Western Powers and the Soviet Union would soon be broken and saw in this the bailout of Romania and Finland. On the other hand, there were those assessing that this break would only occur in the aftermath of their common victory against Germany. This would make it too late for the two states to be saved from Soviet grasp. Finally, in this latter group, there were those believing that Western Powers would arrange an armistice with Germany before the latter would be completely crushed, in order to face the rise of the Soviet threat. Adepts of this theory believed that the two countries would find salvation in opposing militarily resistance that far. Palin considered these interpretations as 'wishful thinking' showing a marked tendency toward capitulation, but also exhibiting deep worries and an increased lack of confidence in the Anglo-Americans. ${ }^{16}$

\section{The German coup in Hungary and the Romanian peace feelers}

The Finnish envoy was willing to get adequate information regarding the conversation between Hitler and Antonescu dated March 23rd $-24^{\text {th }}$. As usually, he addressed the Romanian vice-PM who informed him that Hitler only remarked that Finland had attempted to broker peace, but the Soviet's unreasonable proposals prevented it from being achieved. In exchange, Ribbentrop was more critical on Romania's attempts to negotiate peace. He stated that their sole result would be only an unnecessary weakening of the fighting morale, having become obvious that continue fighting was the only option. Perhaps as a warning, the Germans did not shun reminding about the occupation of Hungary which in their opinions was due to the suspicions that the Hungarian leaders were plotting with the Anglo-Americans and the Soviets, without the consent and knowledge of Germany. In an attempt to downgrade the appearance of a brutal military occupation, Hitler said that the action took place with Horthy's consent and with the trust of the Hungarian army. ${ }^{17}$

Palin received, over the following days, additional information about the reasons which prompted Germany to occupy Hungary. The Finnish Minister quoted the local air attaché as arguing that the Hungarian attempt to prevent

16 Palin's report no. 10 of 16.03.1944, UA, 5, C 14.

17 Palin's dispatch no. 98/97 of 28.03.1944, National Archives of Finland (hereafter, KA), Risto Ryti kokoelma 29. 
traffic of German military trains to Romania via Hungary was the straw that broke the camel's back. As the German troops had occupied Hungary up to Tisza and a new government was to be formed with the German approval, Palin concluded that Hungary ceased to qualify as an independent state. ${ }^{18}$ Another reason which prompted the German action was, Palin transmitted quoting a trustful source, the Hungarian opposition to German request that 20 Hungarian divisions should leave for the Eastern Front. The takeover took place during Horthy's returning trip from Hitler. ${ }^{19}$

Regarding the consequences of the Romanian leadership's visit to Hitler, Palin once more stressed its contribution to the widening gap between the attitudes and opinions of Ion and Mihai Antonescu. The latter, unsolicited to accompany the Marshal in this visit, expressed his opinion that it would have been easier to arrange the visit through normal diplomatic channels. Throughout the visit, Hitler attempted to instil in the Romanian Leader new hopes that the war might yet end successfully. The starting point of the optimistic scenario which Hitler presented to Antonescu was that German military position was superior both in the east and in the west. The attempt of invasion in the west, once repelled, the situation was going to change in the east, too. He estimated that within two-three months Ukraine would be occupied once again. Hitler asked Romania to mobilize all her defensive forces and to transfer the divisions from the country to the frontline. Except for using his watercolour in order to paint an overoptimistic picture of the future, Hitler promised five infantry divisions and one tank division in support, as well as the necessary heavy armament and armoured units for the 12 divisions which were still inside the country and for other 10 other divisions to be mobilized. However, the most important weapon in Hitler's arsenal of convincing Antonescu to remain loyal to the Germans only followed when Hitler, in particular, on his own initiative, told the Marshal that he had become convinced of Romania's rights to the whole Transylvania. This was, indeed, what Antonescu had hoped to hear for years. However, by then, the Romanian leader was no longer inclined to trust every word of the Führer. Germany had always promised new arms - after Stalingrad, when Romania lost its artillery and armour - but nothing had come true. Therefore, Antonescu argued that if Germany's promised support did not come soon the situation would turn catastrophic. Romania could defend for herself against the Soviets for no more than a few weeks. The country had sent and was sending to the Moldovan frontline all her forces, but they were only armed with light weapons and no armoured forces and they were unable to defend for long the frontline 
against the Red Army. The Soviets had already - in many places - crossed the river Prut. The conquering of Iasi and Cernauti loomed ahead. ${ }^{20}$

The Finnish press commented the trip to Ankara and Cairo of former Prime Minister and prominent Romanian politician Prince Barbu Ştirbey. Concerning this trip, all sorts of telegrams were published, including the denials of Rador and Moscow. This trip inspired two articles in Suomen Sosialidemokraatti of March $15^{\text {th }}$ and Svenska Pressen of March 17th. In the first article, it was argued that Romania, a country occupied by the German troops in 1941, joined a war which she did not seek. This did not prevent the Romanian Army to battle bravely up to the Caucasus and to provide the biggest contribution in blood, compared to all other Axis countries, in the struggle against Bolshevism. The newspaper concluded that the approach of the Red Army increased the Romanian opposition to the continuation of the war. The trip of Ştirbey to Cairo was considered proof that Romanians wished to do everything possible to rescue the country from a likely disaster. Svenska Pressen of March 17th took notice of Bucharest's denials, but still underlined that the visit of Ştirbey to Cairo had a deep political meaning. The article then approached the personality of president of former National Peasants' Party Iuliu Maniu and presented the role of Edvard Beneš in defending his former allies, especially Romania. Hufoudstadsbladet of March 17th published a biography of Ştirbey. The telegrams from neutral sources attempted to prove the willingness of Romania to come off well from the war (Bern, Stockholm), the telegrams from Budapest emphasized the panic existing in Romania, while those from London showed the impending regime change in this country. ${ }^{21}$

On April 1st 1944, the Press Bureau of the Romanian Legation in Helsinki sent a new report consisting of two articles published in the Finnish press. The biggest Finnish daily Helsingin Sanomat of April $1^{\text {st }}$ carried an article called Romania under threat. The newspaper stated that Romania's war was not an aggressive one, but aimed at re-conquering territories lost to Soviet Union in 1940. It highlighted the opposition of politicians such as Maniu and National Liberal Party's president Constantin I.C. Brătianu, who constantly considered the deep offensive of the Romanian troops into the Soviet territory to be a mistake. In a short analysis of Romanian foreign policy after 1918, the newspaper considered it to be coherent, aimed at understanding and peace with its neighbours: 'it can be noticed that Romania did not increase its territory on the expense of other countries which collapsed in the meantime and did not take part in the occupation of foreign territories. Quite the contrary, she surrendered territories to Bulgaria in order to extinguish an old conflict and was forced by the Vienna Award to yield a

20 Palin's dispatch no 97 of 28.03.1944, KA, Risto Ryti kokoelma 29, Nippu 3/6.

21 Mihăilescu's report no. 34 of 22.03.1944 to Alexandru Marcu, Arhivele Ministerului Afacerilor Externe (hereafter, MAE), folder 71, Finlanda, vol. 8, 282-290. 
substantial share of Transylvania to Hungary.' The result was that the Czechs and the Serbians maintained the same sympathy towards Romania as they did during the existence of the Little Entente. Regarding the future of Transylvania, a special attention was given to Beneš's declarations and to the fact that the Western powers had supported the Romanian claims over this territory. In conclusion, the article stated that for the moment Romania had no other choice than to continue to defend herself.22 On April 22nd, Helsingin Sanomat carried - from its correspondent in Washington - State Secretary Cordell Hull's warnings that Romania should terminate the cooperation with Germany since USSR had offered her favourable peace conditions. ${ }^{23}$ On the other hand, Romanian press agency Rador on April $3^{\text {rd }}$ noticed that the Swedish political circles gave a great importance to Molotov's declarations regarding Romania. It was considered that the declaration could play a significant role also in the peace negotiations of Finland. As the German propaganda in Sweden and Finland argued that the Soviet Union will conclude a separate peace with Germany when they would reach the Carpathians and the frontiers of 1940, which played an important role in Finland in the retardation of their peace negotiations, Molotov's declaration was the best proof of denial of a separate peace. ${ }^{24}$

Of course, the main channel of information about the realities in Romania remained, for Helsinki, the reports of the Finnish representative in Romania. On March 24th , Palin quoted Maniu's closest collaborator as having told the Finnish envoy that Ştirbey had informed on the results of his peace feelers. They were negative as Britain and the United States had explained that at that moment, they could provide no support to Romania that could be interpreted as a move against Soviet Union. The two powers explained that Soviet Union was still needed in order to defeat Germany. This requested a price that they were prepared to pay. The Allies had explained to Ştirbey that Romania had to trust the British and American governments and extricate from the war, although her future as an independent state could not be guaranteed. Although Romania would become a battleground and an occupied country if she placed her faith into the Allies and ended the war before she was occupied by the Red Army, she could trust the Allies in eventually supporting her. Accordingly, Maniu and Brătianu approached Marshal Antonescu. Antonescu did not want to accept this view and explained in a fit of anger his intention to fight the Soviet Union until the end. ${ }^{25}$

Writing to Helsinki on the last day of March, Palin informed about the tension manifested in German-Romanian relations. The rapid progress of the Red Army

\footnotetext{
22 Mihăilescu's report no. 36 of 1.04.1944 to Alexandru Marcu, AMAE 71 Finland 8, 291-292.

${ }^{23}$ Revue de la presse Finlandaise of 22.04.1944 to Alexandru Marcu, AMAE 71 Finland 8, 301.

24 Rador's communiqué 1662 of 3.04.1944.

25 Palin's dispatch no. 94/83 of 24.03.1944, Risto Ryti kokoelma 29, Nippu 3/6.
} 
contradicted the categorical German assurances. These developments forced Romanians to look for alternative solutions. Palin reported confidentially that when Ştirbey left for Cairo he had been assigned by Antonescu with the task to inquire about the Allied conditions and obtain clarification based on which Romania might end the war. Yet, the Romanian Government claimed that Ştirbey's mission did not resemble that of J.K. Paasikivi because the Romanian emissary was travelling on his own expenses. Palin was unable to give any official information about the results of the Romanian envoy's feelers as Mihai Antonescu claimed to have not received any feedback from Ştirbey. In his dialogue with Palin, the Romanian vice-PM was gloomy about the possibility to conclude peace in the aftermath of the German takeover of Hungary that proved the potential threat of such an action posed on the endeavouring country. Additionally, Mihai Antonescu pointed out a difference between the situation of Finland and that of his country: Romania did not receive an offer of mediation in order to conclude peace from any party, such as was the case with Finland. Palin did consider at this stage of the war the possibility of a quick Soviet advance into Romania and already at this juncture requested instructions in order to prepare himself for such an eventuality. ${ }^{26}$

Quoting a trustful source, Palin reported in mid-April that the Romanian Army was endeavouring to put up a strong resistance on the frontline in Moldova. The possibility that Romanian Army was forced back to the FocşaniGalați line as a consequence of Germany's failure to meet its promises meant the beginning of a separation between the two countries, a fact which Antonescu brought to the knowledge of the local German envoy. In the meantime, Palin learned that the discussions for an armistice had progressed, with the Soviet envoy to Ankara passing his Romanian colleague the Soviet conditions for an armistice, which the Finnish envoy promptly conveyed to Helsinki: Bessarabia and Bucovina returned to Russia; the Soviets assuming control over the Danube Delta and establishing a connection link with Bulgaria; the Romanian military troops fighting beyond Romanian borders lay down their arms; the troops acting within the country are demobilised; the Russian Army is permitted to follow the Germans inside the country; permission is granted to Soviet garrisons to camp in Romania, which meant in fact the occupation of the country. Palin had no information about how the other borders were to be settled, but believed that they would be discussed at the negotiating table of the peace conference. ${ }^{27}$ As Palin later learned, the Marshal wanted that the issues of Bessarabia and Northern Bucovina were to settled only at the peace conference. Antonescu opposed the idea that the troops fighting outside the borders of the country should be

26 Palin's dispatch no. 83 of 31.03.1944, KA, Risto Ryti kokoelma 29, Nippu 3/6.

27 Palin's dispatch no. 119 of 16.04.1944, KA, Risto Ryti kokoelma 29, Nippu 3/1. 
militarily dishonoured. He also considered that troops garrisoned inside the country should be maintained to preserve order without help from the Red Army. Antonescu did not accede to Maniu and Brătianu's requests to agree with the Soviet conditions for peace and broadcast via radio his acceptance, but instead was acting to defend Moldova in an attempt to avoid the sharing of Hungary's fate and gain time for negotiations. However, according to Palin, the Marshal agreed that a turnabout of the military situation would convince him to conclude a separate peace. ${ }^{28}$

By the end of April, Palin informed the Finnish President Ryti and his Foreign Minister about the opinions of the topmost Romanian leaders, Ion and Mihai Antonescu. With trustworthiness, Marshal Antonescu communicated the Finnish envoy his relief for being able to put out peace feelers while having his line of defence and numerous divisions to oppose the Soviet troops. He hoped that in this way he would be successful in securing better peace terms for his country. On the other hand, Mihai Antonescu, continually anxious to avoid the fate of Hungary for his country, considered that by the official nature of her negotiations, Romania proved her worthiness to the Germans. Regarding the substance of the negotiations, the chief of Romania's foreign policy revealed his satisfaction that the Soviet Union did not ask establishment of military bases on Romanian territory. However, he was concerned about the likeliness of Soviet control over the Danube Delta. ${ }^{29}$

Palin continued to be well-acquainted with the development of Romania's negotiations for an armistice. For instance, at the beginning of May 1944, Mihai Antonescu updated him on the latest developments of negotiations taking place in Ankara and Stockholm. Keeping with the cooperation agreed upon between the two states already in July 1941, Antonescu informed Palin that, in Stockholm, the representative of the Soviet Legation had tried to motivate Romania into concluding an armistice on Soviet terms by revealing to the Romanian minister, Frederic Nanu, that Moscow was going to get quite angry because Finland did not take seriously the fact that prolongation of the armistice negotiations affected the Soviet prestige. The Soviet diplomat concluded that Romania had to exploit the auspicious mood in Moscow in order to receive more favourable terms than Finland. ${ }^{30}$ Yet, as Palin asserted, the Romanian leaders were doubtful that the peace terms offered by Soviet Union were positive enough to justify sacrifices and dangers involved in a rupture from the Germans. The vice-PM underscored to Palin that the fact that Romania maintained her peace feelers fully private afforded her to give no reply to Soviet proposals. He also informed the Finnish

28 Palin's dispatch no. 119 of 16.04.1944, KA, Risto Ryti kokoelma 29, Nippu 3/1.

29 Palin's dispatch no. 127/119 of 26.04.1944, KA, Risto Ryti kokoelma 29.

30 Palin's dispatch no. 138 of 3.05.1944, KA, Risto Ryti kokoelma 29. 
envoy on the peace terms which crystallized during discussions between the two parties: the border of 1940 in the east; the Romanian Army joining the Soviets in driving the German troops out of the country; the Soviets to assist the Romanians in retaking Transylvania; during the war operations, the Red Army should have the right to use Romanian railways; no garrisons and no control over the Danube Delta. The Romanian vice-PM stressed that the main difficulty ('an impossible request') was the demand to turn against the Germans, which was particularly troublesome from both a moral and a military point of view. The vice-PM showed himself afraid that Romania might repeat the fate of Hungary. ${ }^{31}$

Palin reported, on May $8^{\text {th }}$, about the worsening of the situation in Romania. He anticipated that 'the time of the final decision' was nearing. He estimated that three political forces existed in Romania that were to be reckoned with. The main issue concerned the conclusion to be derived from the practically unanimous estimation that Germany had lost the war. Connected to Germany both politically and militarily, inflexible to compromises, following a straight line rather as a military man than a politician, the Marshal was bound to continue to fight alongside Germany. He invested his hopes in the idea that the German war forces were in sufficient number to insure the concluding of a peace guaranteeing preservation of his country's independence. Palin anticipated that only in the extreme case that Germany was not going to grant Romania any support it would be able to run off the rails. By comparison, Mihai Antonescu's outlook was influenced less by illusions and ethical restraints. This attitude was due to the fact that in his opinion fidelity to Germany would not safeguard the future of his country. The vice-PM was prepared to accept an armistice whose clauses would be acceptable to his country. Yet, beside the hindrance incurred by the harsh terms of armistice requested by Soviet Union, Mihai Antonescu had also to take into account the consequences of such action as showed by the examples of Hungary and Italy. Palin seemed to have been insufficiently aware of the armistice negotiations which the government pursued in Stockholm. Therefore, he reported that the government tested the reaction of the Soviet Union to an armistice only via the nominally opposition-led negotiations. The results were not positive. The Finnish envoy observed that as a consequence of these negotiations the Germans increased their presence in Romania which might point out to a replay of the occupation of Hungary. Palin however considered that two possibilities could save the vice-PM's policy: a better resistance of troops on the front, or the landing of Anglo-American troops in the Balkans. Thus, for the first time, Palin points out to serious divergences between the lines followed by the two Romanian topmost politicians: Ion Antonescu and Mihai Antonescu. The

31 Palin's dispatch no. 137 of 3.05.1944, KA, Risto Ryti kokoelma 29. 
cooperation between them was far from being as close as it used to be. He reported that the vice-PM was openly criticizing various decisions of the Marshal in his conversations with the Finnish envoy and stated that he would have taken a different course.

Commenting on the actions of Romanian opposition, Palin stated that it still lacked an energetic leader prepared to assume responsibility, given the fact that Maniu and Brătianu were old, prudent and bound to prejudices. This fact hindered translation of their viewpoints into practical politics. The opposition considered that the separation from the Germans had to be achieved, whatever the price. The opposition leaders hoped that as disastrous as it might first appear, the price of this separation would be paid on a provisional basis. The continuation of the war was bound to trigger the ruin of Romania as the country would continue to be a theatre of war. Palin remarked the hesitations of opposition leaders in achieving what they thought it would be right. Palin reported about the Marshal Antonescu's proposal that Maniu and Brătianu should sign, together with him, the armistice with the United Nations which was rejected by the two leaders. Palin is often critical with the two leaders' political actions. He considered, taking into account their assessment, that 'patriotism should demand them to take those actions by means of which their program was to be achieved.' Their immobility made Palin doubtful that, if opposition leaders were at the helm of the government, they would have adopted a different course of action. ${ }^{32}$

In the meantime, conditions in the country were so difficult that carrying out the activities of the legation became increasingly difficult. This would also reflect in the lower number of dispatches from the Finnish Legation in Bucharest which reached the desk of the Foreign Ministry in Helsinki. The dark perspective of a Soviet occupation over the country made Palin consider the possibility that the legation should leave Romania. Palin requested clear instructions for the possibility that a sudden collapse of Romania would prove true the worst expectations. ${ }^{33}$

In his dispatch dated May 27th, Palin reported about the plans of the former king Carol II to return to the helm of the country. Carol was prepared to regain his crown supported by the Soviet Union. According to the Finnish envoy, Carol and the Soviet government wanted to take advantage of one another for advancing their own ends and then to follow their own separate ways. This prospect raised the morale of his former king's friends and associates who had played a significant role in the country's political and economic developments and were eventually persecuted by Antonescu's regime. On the other hand, this prospect led to cooperation - within certain limits - between the government and 
those circles of opposition who had contributed to the overthrowing of the former king, which had every interest to prevent this from happening. Meanwhile, both the circles around Antonescu, who opposed to the harsh terms of armistice proposed by the Soviets but were favourably disposed to concluding a truce on better terms, and the circles of opposition, nurtured hopes that an AngloAmerican landing in the Balkans would afford Romania to prevent concluding her armistice with Soviet Union alone. ${ }^{34}$

Settled in Switzerland, former Foreign Minister Grigore Gafencu persistently tried to dissolve the hopes of his countrymen that the Soviet-Western alliance was but a provisional arrangement. Gafencu shared his views with the Finnish Minister in Bern. He was convinced that Soviet Union was not going to experience an overturn in foreign policy and would remain an ally of the AngloSaxons. Gafencu insisted that only two possibilities were available to Romania and Finland: to conclude an agreement with the Soviet Union or to continue a hopeless war which would end in a collapse under Communist terror. The first alternative implied courage, the second heroism. However, the heroism paradoxically meant fear and the assuming of the uncertainty of peace courage. Gafencu revealed to the Finnish envoy that Romania's unofficial pursue of peace continued. He persisted into pressing the opposition with the idea that only conclusion of an early peace could save Romania. The Finnish envoy also reported to Helsinki about the prospective publication of Gafencu's book Preliminaires de la guerre a l'est 35 .

In the minutes of the conversations between June $20^{\text {th }}$ and July $18^{\text {th }}$ (five meetings were held between Mihai Antonescu and Palin in this period) the main subject of discussion was the Finnish developments leading to the RytiRibbentrop agreement. Mihai Antonescu's request for a confirmation of the information passed by the Finnish envoy to Berlin to his Romanian counterpart that German-Soviet negotiations were under way and Finland preferred to wait for their outcome before taking any action did not receive a clear answer. This led Mihai Antonescu to complain that although Romania's position was to respect the action of concert established in July 1941, Finland manifested reserves after Henrik Ramsay had assumed position of foreign minister. ${ }^{36}$ Eventually, as Palin revealed to his Foreign Ministry, at the end of July 1944 Mihai Antonescu became difficult to reach. He could only meet the secretary general of the Foreign Ministry who informed him that it was difficult for Romania to conclude an

\footnotetext{
34 Palin's report no. 12 of 27.05.1944, UA, 5, C 14.

35 The Legation of Bern's dispatch no. 61 of 21.07.1944 to to the President and the PM, KA, Risto Ryti kokoelma 20.

36 Minutes of conversations between Mihai Antonescu and Palin of 20.06, 27.06, 4.07., 11.07 and 18.07.1944, AMAE Finland 15, 214.
} 
armistice as long as German troops remained in the country, Turkey stayed neutral, and the Anglo-Saxon landing in the Balkans did not occur. Describing his country's situation, the Romanian diplomat emphasised that it was 'tragic' and resembled that of Finland regarding the prospects of the armistice. He also showed concerns regarding the information that Germany and Soviet Union were negotiating in Stockholm the scheme of a separate peace. ${ }^{37}$

\section{The Romanian change of sides: Finnish views}

The Finnish press allocated many columns to Romania's separation from Germany on August 23rd 1944. As the German envoy to Helsinki Wipert von Blücher underlined in his memoirs, this piece of news 'hit the country as a bomb' and contributed to some extent to Finland's decision to undertake a similar course of action. ${ }^{38}$ A series of other sources proved that Blücher's opinion was rooted in realities. In his synthesis on Finland, Pericle Martinescu of the Romanian Foreign Ministry, who had considerable knowledge of Finnish foreign policy, pointed out that Finland followed the example of Romania in separating from Germany. He quoted in this respect an article published on September $21^{\text {st }}$ by Pravda which emphasised that, after Romania - the fundamental support for Germany on the southern front - chose to depart from her comrade-in-arms relation with the Reich, Finland, the most valuable support for Germany on the northern flank, followed Romania's footsteps. ${ }^{39}$

The significance of Romanian developments was understood by politicians in Helsinki, for instance by former President Ryti, who commented on this into his diary. On August 24th, at 15.43, he observed that the turnabout in Romania forced Hungary to prepare for defensive in Transylvania. The Bulgarian reaction to the unexpected situation was also made known to Ryti. A Palin dispatch from Sinaia dated August 24th which reached Ryti's knowledge informed about the creation of a new coalition government in Romania, with Communists included.40 The Finnish Minister in Berlin also approached with his counterpart, General Ion Gheorghe, the meaning of these developments and informed the Finnish authority on the latter's views. ${ }^{41}$ The hopes entertained by Romania from her new policy were also made known to Ryti on August 25th. USSR had expressed its desire to have the Romanians give up their cooperation with Germany and fight against Hungarians and Germans in Transylvania. The enmity between the two

\footnotetext{
37 Palin's letter no. 515 of 30.07.1944 to Henrik Ramsay, UA, 5B Bucharest. Eduard Palin, 1943-1944.

38 Wipert von Blücher, Suomen kohtalonaikoja. Muistelmia vuosilta 1935-1944, trans. Lauri Hirvensalo (Porvoo, Helsinki: Werner Söderström Osakeyhtiö, 1950), 410.

39 Pericle Martinescu's work of 10.02.1945, AMAE Problema 70-71, 1945-1948, Finland.

40 Palin's dispatch no. 523 of 24.08.1944 to Ryti, to the President and the PM and other notes, KA, Risto Ryti Diary, Notebook no. XIV.

${ }^{41} \mathrm{KA}$, Risto Ryti Diary, Notebook no. XIV.
} 
states would be put to an end, and this would contribute to the signing of peace between the Romanians and the Allies. ${ }^{42}$

\section{Conclusions}

The analysis of these diplomatic dispatches shows the extent to which Romania and Finland shared common security threats, how they were forced to make a choice between two foreign threats, bandwagoning Germany and struggling against the Soviet Union. Eventually, following the Battle of Stalingrad, their elites were forced to come to terms with the new circumstances and to look for any possible salvation from a menace which they perceived both in terms of security and ideology. The governmental and opposition leaders in Romania were divided over the best way to handle the situation. Conflicting views could be found inside governmental circles, including the split between Ion and Mihai Antonescu. The opposition sometimes came up with what Palin labelled phantasmagorical projects, sometimes they showed a pronounced lack of plans or courage to carry them out. In the end, when they finally acted, the turnabout of Romania influenced to some extent the moods in Finland. It is obvious when reading these reports that the Finnish envoy was well-informed, and this was largely the result of the July 1941 agreement of exchange of information undertaken by Romania and Finland. Besides, he had resided long enough in Romania in order to be able to create useful contacts in the highest circles of the Romanian society. Moreover, the fact that Finland shared Romanian anxieties and was also sailing between Scylla and Charybdis allowed him and his superiors in Helsinki to better comprehend the hazards of the Romanian situation and the snags behind any decision that could rescue Romania from its menacing situation.

\section{References:}

\section{A. Archives:}

Arhivele Ministerului Afacerilor Externe (MAE), folder 71, Finlanda: vol. 8, vol. 15.

Arhivele Ministerului Afacerilor Externe (MAE): Problema 70-71, 1945-1948, Finlanda

National Archives of Finland (KA), Risto Ryti kokoelma (collection): 20, 29.

National Archives of Finland (KA), Risto Ryti kokoelma (collection): Risto Ryti Diary, Notebook no. XIV

Ulkoasiainministeriön arkisto (UA): 5, C 14 .

Ulkoasiainministeriön arkisto (UA): 5B Bucharest. Eduard Palin, 1943-1944. 
B. Books, articles, testimonies:

Blücher, Wipert von. Suomen kohtalonaikoja. Muistelmia vuosilta 1935-1944. Trans. Lauri Hirvensalo. Porvoo, Helsinki: Werner Söderström Osakeyhtiö, 1950.

Miloiu, Silviu. "From "allies without alliance" to concerted action: Romania and Finland in the aftermath of the Operation Barbarossa (1941)." Revista Română pentru Studii Baltice şi Nordice / The Romanian Journal of Baltic and Nordic Studies. Vol. 2, Issue 2, 2010: 249-284.

Walt, Stephen M. "Alliances: balancing and bandwagoning." At http://www.ou.edu/uschina/texts/WaltAlliances.pdf. 